\title{
DEVELOPMENT OF THE DESIGN AND DETERMINATION OF THE MODE CHARACTERISTICS OF THE DEMINERALIZER FOR SEA WATER
}

Oleg Burdo', Igor Bezbakh', Yana Fatieieva ${ }^{3}$, Aleksandr Zykov, Petr Osadchuk, Igor Mazurenko $^{6}$, Shao Zhengzheng ${ }^{7}$ Lyudmila Phylipova ${ }^{8}$

${ }^{1}$ Department of Processes, Equipment and Energy Management, Odessa National Academy of Food Technologies, Odessa, Ukraine burdo.onaft@gmail.com

ORCID: https://orcid.org/0000-0002-2630-1819

${ }^{2}$ Department of Processes, Equipment and Energy Management, Odessa National Academy of Food Technologies, Odessa, Ukraine igorbezbakh1003@gmail.com

ORCID: https://orcid.org/0000-0002-2353-1811

${ }^{3}$ Department of Processes, Equipment and Energy Management, Odessa National Academy of Food Technologies, Odessa, Ukraine yana.maselska@gmail.com

ORCID: https://orcid.org/0000-0002-6262-5300

${ }^{4}$ Department of Processes, Equipment and Energy Management, Odessa National Academy of Food Technologies, Odessa, Ukraine zav380@yahoo.com

ORCID: https://orcid.org/0000-0001-8345-1015

${ }^{5}$ Department of Agroengineering, Odessa State Agrarian University, Odessa, Ukraine petrosadchuk@ukr.net

ORCID: https://orcid.org/0000-0003-3312-0669

${ }^{6}$ Hunan University of Humanities, Science and Technology, Loudi City, Hunan, China 0487222489@ukr.net

ORCID: https://orcid.org/0000-0003-2233-7563

${ }^{7}$ School of Food Science, Henan Institute of Science and Technology, Xinxiang, China ORCID: https://orcid.org/0000-0001-9776-133X

${ }^{8}$ Research and Design Institute for Standardization and Technology of Eco-Friendly and Organic Products, Odessa, Ukraine 1_philipova@ukr.net

A R T ICLE INF O
Article history:
Received date 25.03 .2021
Accepted date 22.04 .2021
Published date 30.04 .2021
Section:
Food production
D O I

$10.21303 / 2313-8416.2021 .001814$

KEYWORDS

block low-temperature plants sea water

desalination, salinity

\section{ABSTRACT}

The object of research is block low-temperature installations for obtaining fresh water. Investigated problem: obtaining fresh water from sea using low-temperature technologies. Main scientific results: the design is developed and the operating characteristics of the demineralizer for sea water are determined.

The influence of the initial salt content of sea water on the ice formation rate is determined. With an increase in the salinity of 3.5 times, productivity on ice decreases 2.3 times.

The kinetics of the salt content in the freezing solution depends on the initial concentration. With an initial salt content of $6.74 \mathrm{~g} / \mathrm{l}$, the process rate is $0.4 \mathrm{~g} / \mathrm{h}$, with a salt content of $1 \mathrm{~g} / 1-0.14 \mathrm{~g} / \mathrm{h}$

With an initial salt content of $6.74 \mathrm{~g} / 1$, the process of separating wastewater from the ice block is more intensive. The salt content of the first portion of the effluent is 3.2 times higher than the initial concentration of the solution.

A cryoscopic curve was obtained for seawater in the concentration range from 0 to $6.74 \mathrm{~g} / 1$.

The area of practical use of the research results: studies of the quality of the obtained water showed that the content of nitrates decreases 5 times, the hardness decreases by $2 \mathrm{mg} /$ $\mathrm{dm}^{3}$. The salt content is reduced from $858 \mathrm{mg} / \mathrm{dm}^{3}$ to $560 \mathrm{mg} / \mathrm{dm}^{3}$.

Plants for the concentration of food liquids by the block freezing method are designed to produce environmentally friendly products that preserve the bioactive complex of raw materials as much as possible with minimal energy consumption.

An innovative technological product: design and operating modes of a block freezing plant for seawater desalination.

Scope of application of the innovative technological product: industrial enterprises, the technological process of which requires small volumes of fresh water; to obtain fresh water on oil platforms in the oceans; small hotels, boarding houses on the seaside.

(C) The Author(s) 2021. This is an open access article under the Creative Commons CC BY license

\section{Introduction}

\section{1. The object of research}

The object of research is block low-temperature installations for obtaining fresh water. 


\section{2. Problem description}

An increase in the world's population, about 80 million people a year, is depleting the world's drinking water supply. Most of the villagers migrate to megacities. In the future, urban areas will experience a shortage of fresh water from conventional wastewater treatment plants.

Sea water is an important supplement to the water source in many countries (China, India). Desalination of sea water is developed as a separate industry [1].

One of the solutions to water supply problems is to use seawater as a fresh source.

Seawater desalination technologies have been significantly optimized. Specific energy consumption of modern installations is from 3 to $4 \mathrm{kWh} / \mathrm{m}^{3}$ [2]. However, desalination technologies still remain energy-intensive and require technical improvement.

\section{3. Suggested solution to the problem}

The described problem can be solved by applying seawater desalination using reverse osmosis, electrodialysis, direct osmosis, multistage distillation, and freezing.

Renewable energy sources are used as an energy source for desalination plants. For example, ocean waves. The disadvantage of such systems is instability in operation, high cost of the system [3].

At receiving terminals, liquefied natural gas must be re-gasified using the heat of the environment. Usually sea water is used for these purposes. In works [4, 5], methods of using the energy of liquefied natural gas for freezing and desalination of sea water are considered. Compared to other freeze desalination methods, the large contact area between water and air and the low thermal resistance result in a higher energy efficiency [6].

Electrodialysis is considered to be a highly efficient technology for seawater desalination. However, it is considered too energy-intensive process [7].

For reverse osmosis installations, the value of specific energy consumption is 3.5$4.5 \mathrm{kWh} / \mathrm{m}^{3}$ [8]. During the operation of such installations, there are high pressures and additional work on replacing membranes.

In work [9], the design of a compact multistage membrane distillation system was investigated. Installation capacity is $241 /$ day.

Desalination of seawater using sunlight is a sustainable production of fresh water that contributes to solving the global water scarcity [10].

Artificial mixtures are often used in experimental studies to replace seawater, which is a disadvantage when scaling the results.

Work [11] is aimed at developing a batch crystallizer for freezing seawater desalination. The experiments were carried out with $\mathrm{NaCl}$ solutions in water and with seawater samples from Nice, Rabat and Marseille. The process includes a freezing stage and a sweating stage. In the experiments, a salinity of less than $0.5 \mathrm{~g} / \mathrm{kg}$ was achieved, which corresponds to the norms of drinking water. The duration of the entire process was up to 8 hours ( 5 hours for freezing and 3 hours for perspiration).

The Odesa National Academy of Food Technologies has developed a design for freezing sea water [12]. Plate crystallizers are immersed in a container with sea water. A block of ice is frozen on the surface of the mold. The block of ice is removed from the solution, separation is carried out. At ambient temperature, salt solution flows out of the pores of the ice.

The aim of research is to develop designs and determine the operating parameters of block cryoconcentrators for seawater desalination.

\section{Materials and methods}

The Black Sea water is used as the initial seawater. Experimental studies of the kinetics of the process of demineralization of sea water were carried out on the installation, which is shown in Fig. 1. Sea water (product) 4 was pre-cooled and poured into the concentrator 2 , which is made in the form of a thermally insulated rectangular container. The concentrator had the ability to move vertically. Along the axis of the concentrator, two crystallizers 3 , made in the form of plates, are fixedly installed. This shape of the mold provided the simplicity of removing the block of ice 1 from the surfaces of the molds. 
The crystallizer is made of a stainless plate, inside of which a system of evaporation and steam outlet channels is mounted. The refrigerant flow rate was controlled using a throttle valve 5. The temperatures of the liquid and the evaporator surface are measured using a brand pyrometer. The pressure and boiling point of freon in the crystallizer are determined by the readings of the MTK 1059 monovacuum meter.

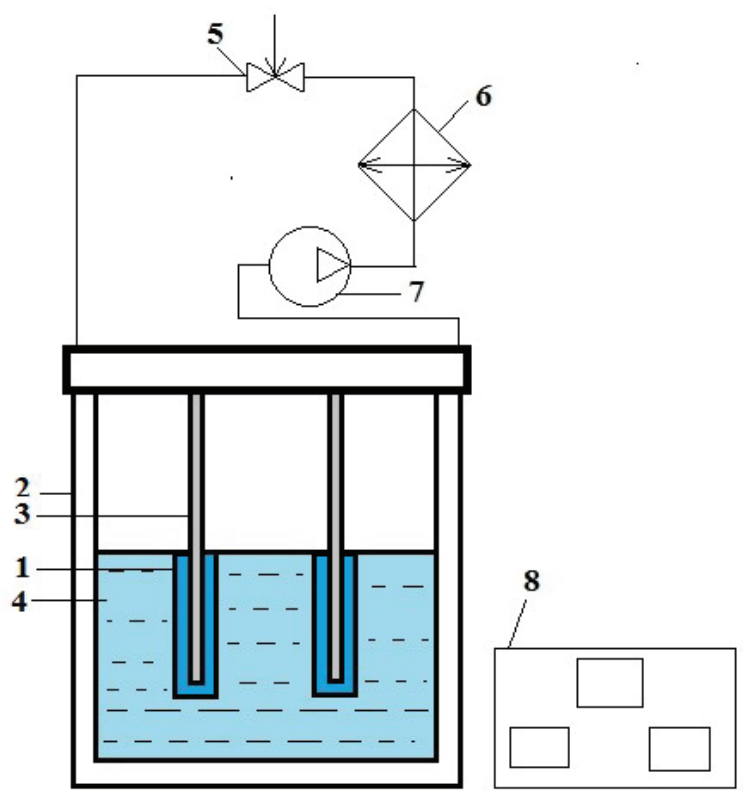

Fig. 1. Diagram of the experimental installation: 1 - ice; 2 - hub; 3 - crystallizer; 4 - product; 5 throttle valve; 6 - capacitor; 7 - compressor; 8 - measuring devices

After the completion of the freezing process, the block of ice together with the crystallizer was removed from the solution. Removal of the block of ice from the crystallizer was carried out by changing the direction of movement of the heat flow. For this, the mode switch was set to the "Defrost" position. The voltage was applied to the solenoid valve, and the vapors of the hot refrigerant from the compressor, bypassing the condenser, entered the crystallizer.

In the experiments, the geometric dimensions of the ice block, the volume of the sea water solution and the salt content in it were measured periodically. The salinity of the solution was measured using a saline meter. Only seawater was used in freezing experiments. Initially, water with the maximum salt content was used; for subsequent experiments, desalinated water obtained from the previous ones was used.

It is known that the process of the formation of a solid phase (ice) is characterized by isothermality for very dilute solutions and a jump in temperature in the volume for saturated solutions. The fixation of such a jump is provided in the stand for the study of cryoscopic temperatures (Fig. 2).

The main component of the stand is a cryostat. It is a metal block made of a material with a high coefficient of thermal conductivity and compatible with the investigated product. The block contains an open sleeve where the product is poured. A sensor is placed in the center of the sleeve, which is centered with a special washer made of stainless steel with a thickness of $0.1 \mathrm{~mm}$. The sensor is inserted into a sealed capillary and connected to the tablet. A special program has been developed to record the sensor readings and plot graphical dependencies.

Since the determination of cryoscopic temperatures is carried out in a non-stationary mode, special attention is paid to the issue of reducing the inertia of the sensor and its thermal contact with the solution. The advantage of the computerized experiment system is that the desired temperature jump is recorded clearly and reliably.

It is important to clearly record the temperature jump and the temperature level at which the phase transition occurs. It is also necessary to register the beginning of the ice supercooling process. 
The working section of the cryostat has the shape of a cylinder with walls of heat-conducting metal $40 \mathrm{~mm}$ thick. This helps to smooth out temperature fluctuations in the volume of the product. The system provided fast-response temperature measurement in the volume of the solution with an accuracy of at least $0.1^{\circ} \mathrm{C}$. The cylinder (Fig. 2) contained $2 \mathrm{~cm}^{3}$ of sea water. The refrigerating machine and reliable thermal insulation of the chamber ensured the temperature level in the cryostat up to minus $20^{\circ} \mathrm{C}$.

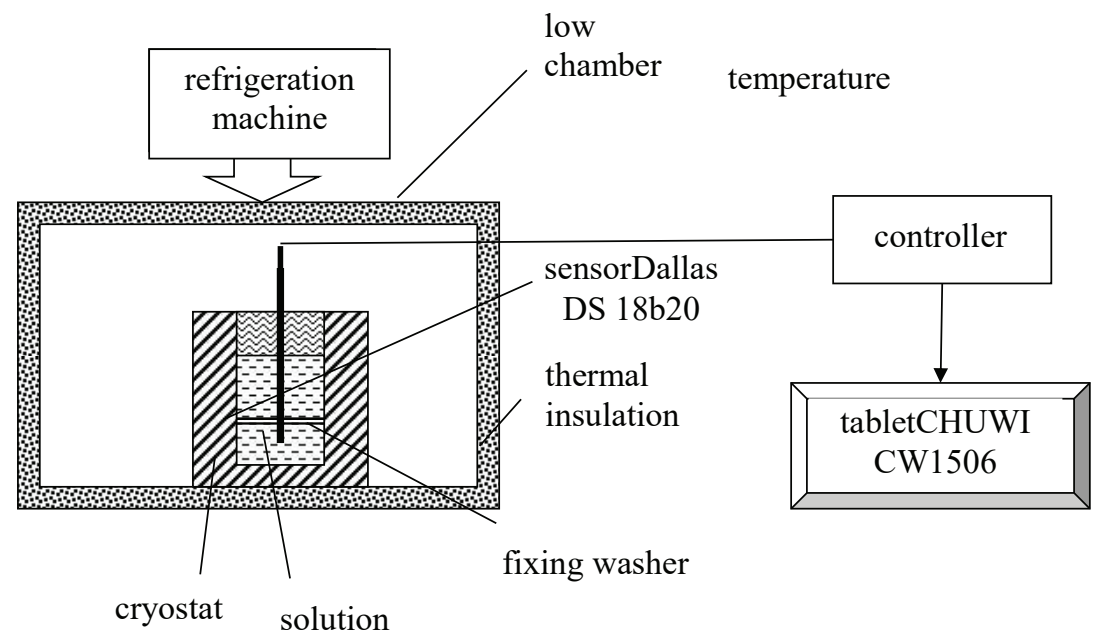

Fig. 2. Scheme of the stand for determining the freezing point depression temperature

\section{Results}

The results of studying the process of ice formation are shown in Fig. 3.

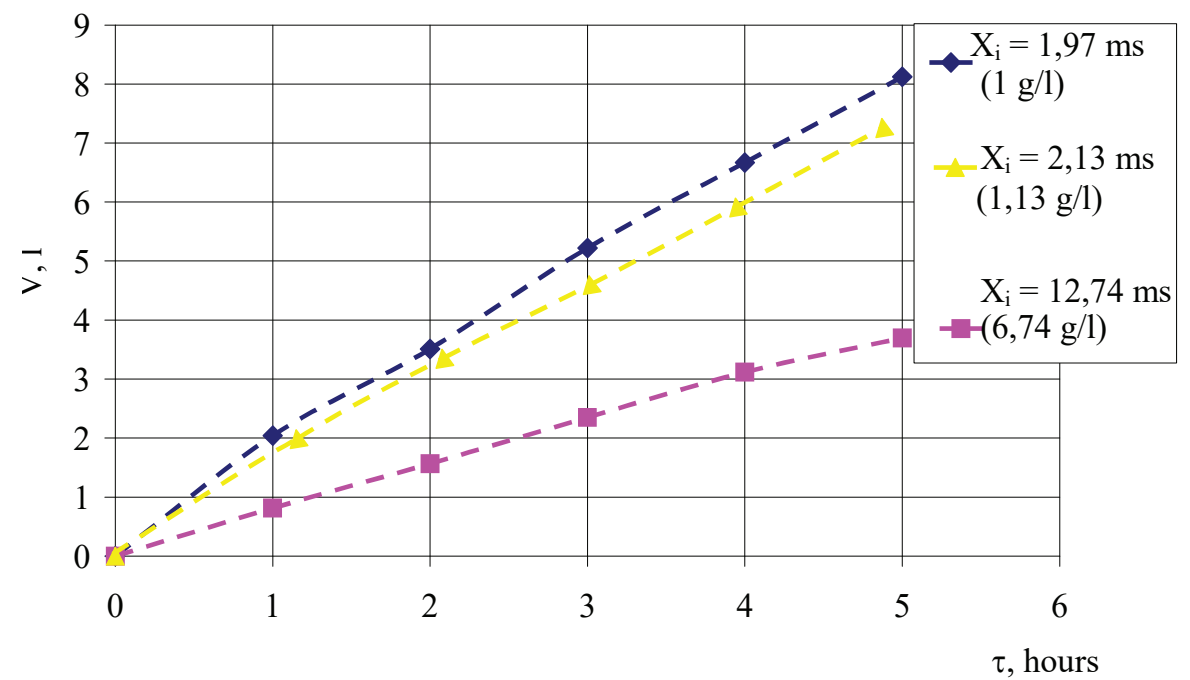

Fig. 3. Kinetics of ice block formation: $x_{i}$-initial salt content, $\% ; V$-ice block volume, 1

In the process of ice block formation, the salt content in the sea water solution increases (Fig. 4).

Analysis of Fig. 3 shows that the initial salt content significantly affects the intensity of the process of demineralization of sea water by freezing.

The efficiency of the technology of desalination by freezing is determined not only by the intensity of the crystallization process, but also by the process of separating the solution from the porous structure of the ice block.

The study of the separation process was carried out according to the following method. Runoffs from the ice block were periodically collected and their salinity was measured using a salt meter. The research results are shown in Fig. 5. 


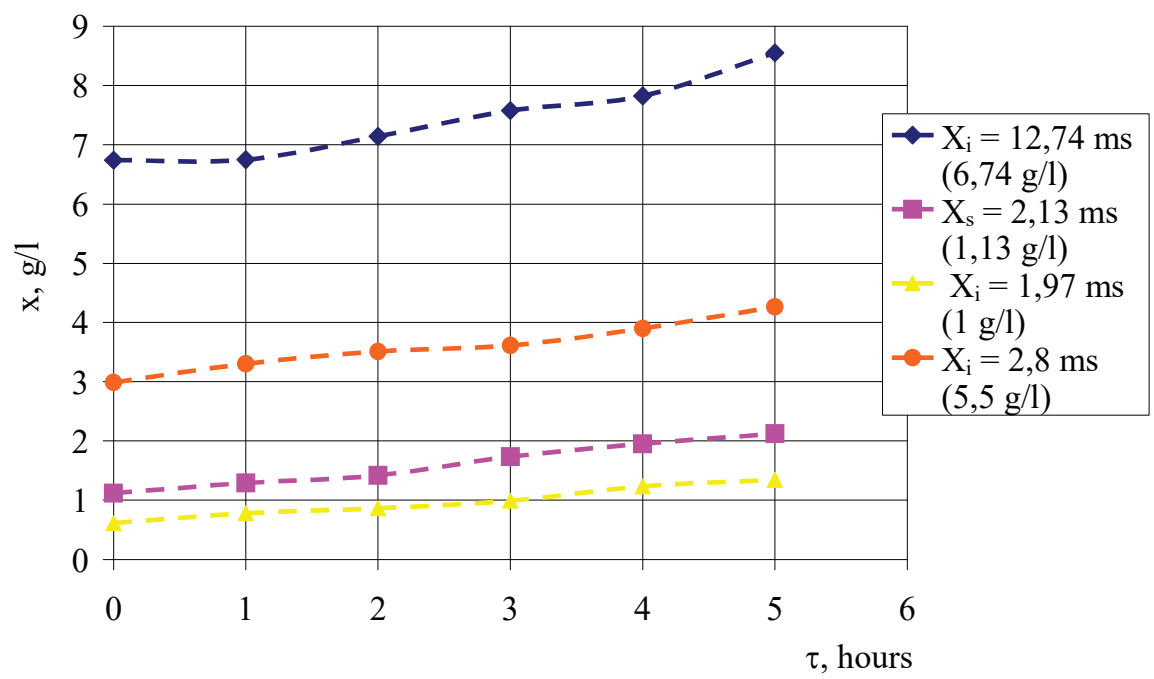

Fig. 4. Kinetics of salinity increase: $x_{i}-$ initial salinity, $\%$

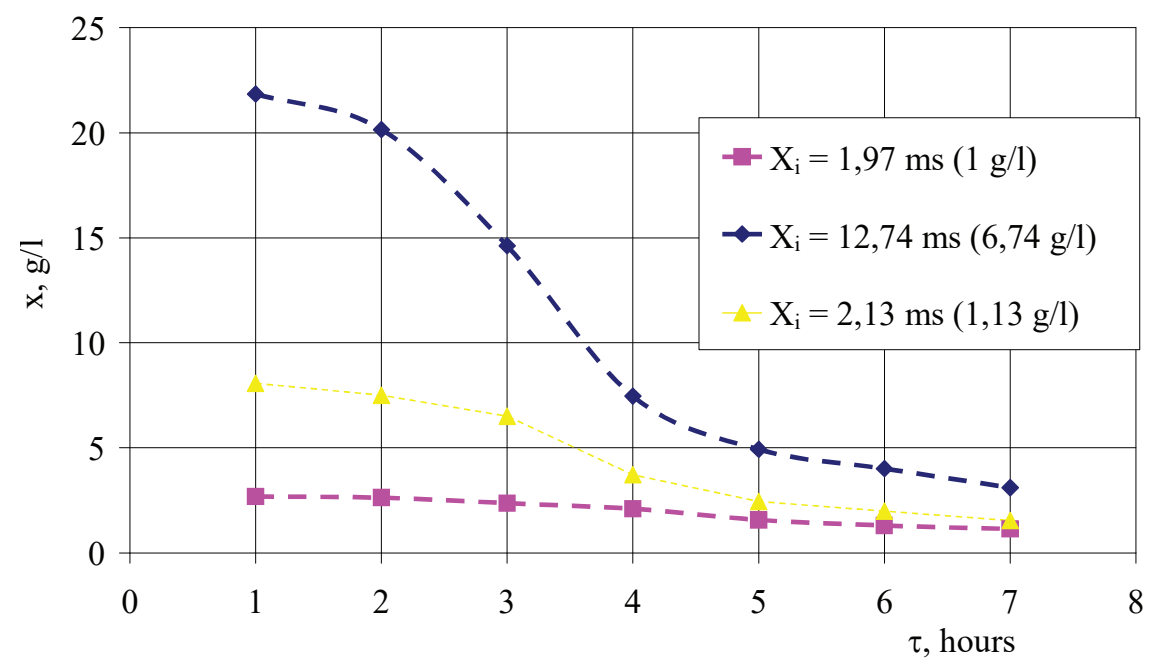

Fig. 5. Changes in the salinity in the effluent: $x_{i}-$ initial salinity, $\%$

A database has been obtained on the effect of water salinity on the nature of temperature changes in the processes of solution cooling, ice crystallization and its overcooling. The graphical dependences illustrate clear patterns in the concentration range from 0 to $6.74 \mathrm{~g} / 1$. The lines of constant temperature recorded the conditions of ice formation, the values of cryoscopic temperatures.

The set of values of cryoscopic temperatures (average temperatures of ice formation processes) express a generalized cryoscopic curve (Fig. 6).

The resulting dependence is necessary to determine the driving forces and kinetic coefficients in the problems of mass transfer.

Using indicator tests, the following parameters of seawater were determined: nitrates $\left(\mathrm{NO}_{3}\right)$, nitrites $\left(\mathrm{NO}_{2}\right)$, carbonate hardness $(\mathrm{kH})$, water index $(\mathrm{pH})$, phosphates $\left(\mathrm{PO}_{4}\right)$, ammonia/ammonium $\left(\mathrm{NH}_{3 / 4}\right)$, as well as salt content. Also, the tap water of Odessa was tested for similar indicators. The results are shown in Table 1.

The presence of nitrates and nitrites, ammonia and ammonium in the water indicates the pollution of water bodies. Since the rivers flowing into the Black Sea are polluted with industrial wastewater, fertilizer washout from fields and vegetable gardens, the presence of nitrates and nitrites in seawater is higher than in tap water, as is the presence of ammonia and ammonium.

An innovative method of desalination is not only to reduce the salt content in the demineralized water, but also to check the quality of the water produced. 


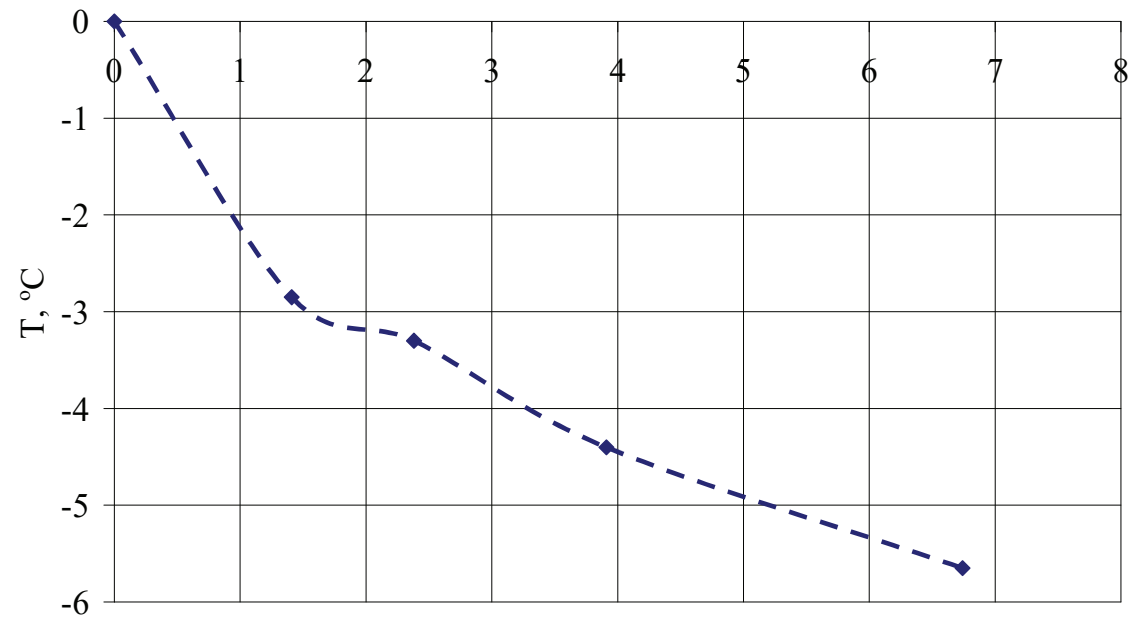

$\mathrm{x}, \mathrm{g} / \mathrm{l}$

Fig. 6. Cryoscopic curve for sea water

Table 1

Water quality indicators

\begin{tabular}{cccccc}
\hline No. & Indicator & Norms & Sea water & Tap water & Desalinated water \\
\hline 2 & $\mathrm{NO}_{3}$ & $\leq 50 \mathrm{mg} / \mathrm{dm}^{3}$ & $10 \mathrm{mg} / \mathrm{dm}^{3}$ & $5 \mathrm{mg} / \mathrm{dm}^{3}$ & $2 \mathrm{mg} / \mathrm{dm}^{3}$ \\
3 & $\mathrm{NO}_{2}$ & $\leq 0.5(1.0) \mathrm{mg} / \mathrm{dm}^{3}$ & $0.05 \mathrm{mg} / \mathrm{dm}^{3}$ & $0 \mathrm{mg} / \mathrm{dm}^{3}$ & $0.05 \mathrm{mg} / \mathrm{dm}^{3}$ \\
4 & $\mathrm{kH}$ & $\leq 7.0(10,0) \mathrm{mg} / \mathrm{dm}^{3}$ & $7 \mathrm{mg} / \mathrm{dm}^{3}$ & $7 \mathrm{mg} / \mathrm{dm}^{3}$ & $5 \mathrm{mg} / \mathrm{dm}^{3}$ \\
5 & $\mathrm{PO}_{4}$ & $\leq 3.5 \mathrm{mg} / \mathrm{dm}^{3}$ & $0.05 \mathrm{mg} / \mathrm{dm}^{3}$ & $0.25 \mathrm{mg} / \mathrm{dm}^{3}$ & $0.05 \mathrm{mg} / \mathrm{dm}^{3}$ \\
6 & $\mathrm{NH}_{3 / 4}$ & $0.5(2.6) \mathrm{mg} / \mathrm{dm}^{3}$ & $0.25 \mathrm{mg} / \mathrm{dm}^{3}$ & $0 \mathrm{mg} / \mathrm{dm}^{3}$ & $0.25 \mathrm{mg} / \mathrm{dm}^{3}$ \\
7 & Salt content & $200-500 \mathrm{mg} / \mathrm{dm}^{3}$ & $858 \mathrm{mg} / \mathrm{dm}^{3}$ & - & $560 \mathrm{mg} / \mathrm{dm}^{3}$
\end{tabular}

\section{Discussion}

It is proposed to exclude auxiliary equipment from the technological scheme: pumps, intermediate tanks, etc. Organize the process on a cold surface of an ice block with a dense packing of crystals. Advantages of block freezing technology:

- no energy losses in auxiliary units;

- simplicity of the mold design;

- ease of implementation of effective gravity separation;

- low power consumption.

Disadvantages low - productivity compared to thermal and mechanical methods of desalination.

The initial temperature, ice growth rate and salinity of the solution are parameters that affect the ice purity. Ice block separation can effectively complete water purification. The duration of the entire process is $7 \mathrm{~h}$, which is shorter than in work [11]. In addition, in comparison with studies [11], only sea water was used; model $\mathrm{NaCl}$ solutions were not used. The salt concentration reached $0.5 \mathrm{~g} / \mathrm{kg}$, which corresponds to the standards for drinking water.

The limitations of the study are the temperature ranges of the solution $0 \ldots-6{ }^{\circ} \mathrm{C}$ and the salinity of seawater $1 . .6 .74 \mathrm{~g} / 1$.

Prospects for further research - to increase productivity, to conduct research for other regions, not only the Black Sea. Plants for the concentration of food liquids by the block freezing method are designed to obtain environmentally friendly products that preserve the bioactive complex of raw materials as much as possible with minimal energy consumption: industries;

- liquid food colorings and flavorings from the waste of wine-making and canning

- whey protein concentrate;

- concentrated juices, extracts. 


\section{Conclusions}

The design and operating characteristics of a demineralizer for sea water were determined.

The influence of the initial salt content of sea water on the ice formation rate was determined. With an increase in the salinity of 3.5 times, productivity on ice decreases 2.3 times.

The kinetics of the salt content in the freezing solution depends on the initial concentration. With the maximum initial salt content in the experiments of $6.74 \mathrm{~g} / \mathrm{l}$, the process rate is $0.4 \mathrm{~g} / \mathrm{h}$, with a minimum $1 \mathrm{~g} / \mathrm{l}-0.14 \mathrm{~g} / \mathrm{h}$

With an initial salt content of $6.74 \mathrm{~g} / \mathrm{l}$, the process of separating wastewater from the ice block is more intensive, which indicates that at a higher initial salt content, the ice block has a more porous structure. The salt content of the first portion of the effluent is 3.2 times higher than the initial concentration of the solution.

A database was obtained on the effect of water salinity on the nature of temperature changes in the processes of solution cooling, ice crystallization and its overcooling in the concentration range from 0 to $6.74 \mathrm{~g} / 1$.

Studies of the quality of the obtained water showed that the content of nitrates decreases 5 times, the hardness decreases by $2 \mathrm{mg} / \mathrm{dm}^{3}$. The salt content is reduced from $858 \mathrm{mg} / \mathrm{dm}^{3}$ to $560 \mathrm{mg} / \mathrm{dm}^{3}$.

\section{References}

[1] Lin, S., Zhao, H., Zhu, L., He, T., Chen, S., Gao, C., Zhang, L. (2021). Seawater desalination technology and engineering in China: A review. Desalination, 498, 114728. doi: http://doi.org/10.1016/j.desal.2020.114728

[2] Elimelech, M., Phillip, W. A. (2011). The Future of Seawater Desalination: Energy, Technology, and the Environment. Science, 333(6043), 712-717. doi: http://doi.org/10.1126/science.1200488

[3] Leijon, J., Boström, C. (2018). Freshwater production from the motion of ocean waves - A review. Desalination, 435, $161-171$. doi: http://doi.org/10.1016/j.desal.2017.10.049

[4] Xie, C., Zhang, L., Liu, Y., Lv, Q., Ruan, G., Hosseini, S. S. (2018). A direct contact type ice generator for seawater freezing desalination using LNG cold energy. Desalination, 435, 293-300. doi: http://doi.org/10.1016/j.desal.2017.04.002

[5] Ong, C. W., Chen, C.-L. (2019). Technical and economic evaluation of seawater freezing desalination using liquefied natural gas. Energy, 181, 429-439. doi: http://doi.org/10.1016/j.energy.2019.05.193

[6] Liu, Y., Ming, T., Wu, Y., de Richter, R., Fang, Y., Zhou, N. (2020). Desalination of seawater by spray freezing in a natural draft tower. Desalination, 496, 114700. doi: http://doi.org/10.1016/j.desal.2020.114700

[7] Doornbusch, G., van der Wal, M., Tedesco, M., Post, J., Nijmeijer, K., Borneman, Z. (2021). Multistage electrodialysis for desalination of natural seawater. Desalination, 505, 114973. doi: http://doi.org/10.1016/j.desal.2021.114973

[8] Voutchkov, N. (2018). Energy use for membrane seawater desalination - current status and trends. Desalination, 431, 2-14. doi: http://doi.org/10.1016/j.desal.2017.10.033

[9] Alawad, S. M., Khalifa, A. E. (2021). Performance and energy evaluation of compact multistage air gap membrane distillation system: An experimental investigation. Separation and Purification Technology, 268, 118594. doi: http://doi.org/10.1016/ j.seppur.2021.118594

[10] Fujiwara, M., Takahashi, K., Takagi, K. (2021). Improvement of condensation step of water vapor in solar desalination of seawater and the development of three-ply membrane system. Desalination, 508, 115051. doi: http://doi.org/10.1016/ j.desal.2021.115051

[11] Rich, A., Mandri, Y., Mangin, D., Rivoire, A., Abderafi, S., Bebon, C. et. al. (2012). Sea water desalination by dynamic layer melt crystallization: Parametric study of the freezing and sweating steps. Journal of Crystal Growth, 342 (1), 110-116. doi: http://doi.org/10.1016/j.jcrysgro.2011.03.061

[12] Burdo, O. H., Reminna, L. P., Kovalenko, O. O. (2008). Pat. No. 34280 UA. Sposib otrymannia kontsentrovanykh ridkykh produktiv shliakhom vymorozhuvannia. MPK: A23L 2/08. No. u200801496; declareted: 05.02.2008; published: 11.08.2008, Bul. No. 15. Available at: https://uapatents.com/3-34280-sposib-otrimannya-koncentrovanikh-ridkikh-produktiv-shlyakhom-vimorozhuvannya.html 